\title{
Entrepreneurial failure and economic crisis: an historical perspective
}

Book or Report Section

Accepted Version

Casson, M. (2015) Entrepreneurial failure and economic crisis: an historical perspective. In: Hollow, M., Akinbami, F. and Michie, R. (eds.) Complexity and Crisis in the Financial System: Critical Perspectives on the Evolution of American and British Banking. Edward Elgar, Cheltenham, pp. 36-59. ISBN 9781783471324 Available at http://centaur.reading.ac.uk/49602/

It is advisable to refer to the publisher's version if you intend to cite from the work. See Guidance on citing.

Publisher: Edward Elgar

All outputs in CentAUR are protected by Intellectual Property Rights law, including copyright law. Copyright and IPR is retained by the creators or other copyright holders. Terms and conditions for use of this material are defined in the End User Agreement. 


\section{www.reading.ac.uk/centaur}

\section{CentAUR}

Central Archive at the University of Reading

Reading's research outputs online 


\title{
Entrepreneurial Failure and Economic Crisis: An Historical Perspective
}

\author{
Mark Casson
}

Word count (total, including Abstract, Tables): 9344

Keywords: CRISIS; HISTORY: FAILURE; MISTAKE; JUDGEMENT; ENTREPRENEUR; BUSINESS

Fourth draft: 26 October 2014

Address for correspondence:

Mark Casson

Centre for Institutional Performance

Department of Economics

University pf Reading

Whiteknights

Reading RG6 6AA

E-mail: $\underline{\text { m.c.casson@ @reading.ac.uk }}$

Tel: (44) (0) 1183788227 


\begin{abstract}
This chapter analyses the major UK economic crises that have occurred since the speculative bubbles of the seventeenth century. It integrates insights from economic history and business history to analyse both the general economic conditions and the specific business and financial practices that led to these crises. The analysis suggests a significant reinterpretation of the evidence - one that questions economists' conventional views.
\end{abstract}

Crises are usually considered to be financial, but historical evidence suggests that their origins are often real. Real effects involve too much investment in some sectors, too little investment in others, and often too much investment overall. These mistaken investment decisions originate in flawed judgements made by entrepreneurs acting under the influence of simple and misleading ideas. The financial aspects of a crisis are often the consequences of a real crisis, aggregated by defaults on fixed-interest debt and the consequent dislocation of the banking system.

The evidence suggests that major crises often involve excessive investment in specific sectors that were considered at the time to be of great strategic importance. Whilst some crises are caused mainly by failures of government policies, failures of privately-funded schemes created the most serious problems. Furthermore, whilst some crises were caused by wars and their aftermath, many were entirely peace-time phenomena.

Theories of entrepreneurship are well-equipped to explain such patterns of behaviour. They emphasise that business decision-making is based on costly and untrustworthy information. Under normal conditions a diversity of opinion exists and, as a result, entrepreneurs are encouraged to collect detailed information on investment projects. But when a single opinion becomes dominant detailed information may be ignored and opinion alone may be used as a guide to decisions. When a reputable elite endorses an over-simplified view about the strategic importance of some particular sector many entrepreneurs may be misled, and so mistakes can be made on a large scale.

Developing and testing a theory of this type requires source material relating to the state of the economy, the behaviour of elites, and the attitudes of entrepreneurs, and therefore benefits from the integration of economic and business history as exemplified in this chapter. 


\section{Introduction}

While most economists failed to predict the Banking Crisis of 2007, the crisis should have come as no surprise to economic and business historians. There are many historical precedents, including the dotcom bubble of 2000, the mortgage crisis of 1972, and the Great Depression 1929-33, triggered by the Wall Street Crash. During the Baring Crisis of 1890 London banks rallied round to save a London merchant bank that had lent too much to the Mexican government. In 1866 the collapse of bankers Overend Gurney was caused by excessive speculation in railway shares. The sorry story of boom and bust can be traced back to the South Sea Bubble of 1720 and even earlier.

The current crisis has been imputed to a failure in wholesale financial markets, and popularised as the 'credit crunch'. On this view, the origins of the crisis are financial. The recession, involving sharp reductions in output and a rise in unemployment, represents the real consequences of these financial failings, it is said, caused by the contraction of business investment and consumer expenditure as borrowing becomes more difficult (Narian, Otket and Pazarbasiglu, 2012).

This chapter suggests, however, that banking problems are often symptoms rather than causes of crises. The underlying problem is usually mistaken judgements made by business and government. These judgements typically involve the over-valuation of innovations, with each cycle of boom and bust being associated with the overvaluation of a particular type of product or innovation. Investment in the innovative sector is excessive, and investment in other sectors becomes too low, as speculative funding switches sectors (Hayek, 1933). The excessive investment in the innovative sector fails to generate the expected profits, and over-confident entrepreneurs who have borrowed heavily become insolvent as a result.

Overconfidence usually comes from a belief that the economy is entering a 'new era', ushered in by some distinctive radical innovation. This innovation becomes overvalued. In the dotcom bubble internet firms were valued using 'new era' accounting principles based on sales rather than profit. The share-price boom before the Great Depression was justified in terms of a new era of mass advertising and mass production, and so on. In the nineteenth century railways were perceived to be a revolutionary force in shrinking space and time, while in the eighteenth century trade and colonisation promised perpetual monopoly profits.

The perceived opportunity to profit from the new type of radical innovation creates a demand for financial loans. There is often international rivalry to exploit new innovations, so politicians get involved as well. As a result, business leaders and politicians induce banks to make excessive loans. Businessmen demand the loans and government relaxes regulations to allow them to be made. Regulations are relaxed in response to the political overconfidence in the innovation.

A specific feature of the recent crisis is that over-valued innovations related to the banking sector itself. Government persuaded the public that boom and bust had been abolished, thanks to central bank independence and 'light touch' banking regulation. The banks, meanwhile, believed that they had made major innovations in the 
evaluation and management of financial risk. As a result, the mistakes made by banks extended beyond the usual problem of over-lending, to investing in new financial products that they did not know how to value. Overconfidence in the banking sector also encouraged banks to lend to each other, thereby exacerbating domino effects in which the collapse of one bank led to the collapse of others.

Innovation has not only a physical dimension - such as investment in new technologies and infrastructure - but an institutional dimension too (Schumpeter, 1939). Chartered trading companies, turnpike trusts, joint stock railway companies, multinational corporations, 'lean' corporations, internet marketing companies and venture capitalists have all been important institutional innovations in their time. The way these institutions are designed and funded have important implications for financial stability. Some of these types of institution have survived, but other soon outlived their usefulness. Likewise new product innovations relate not only to manufactured products such as i-Phones but to new legal and financial products, such as complex financial derivatives.

The timing of a crisis is often identified with the appearance of its symptoms $-e . g$. headline indicators such as rising interest rates and spreads, and falling assets prices but the roots of a crisis often lie much earlier, when an underlying problem developed (Calamiris and Gorton, 1991; Gertler, Hubbard and Kashyap, 1991). The indicators move only when opinion moves, and opinion moves only with a lag - once mistakes have been recognised. This lag allows a crisis to build up undetected. A crisis often emerges as a liquidity problem, in which firms experience a shortage of cash to pay wages and other bills. A liquidity problem can sometimes arise in response to temporary disruptions, such as a strike or natural disaster, and can be resolved through a short-term increase in the money supply. In a crisis, however, liquidity problems usually disguise insolvency.

Insolvency means that resources borrowed by the institution have been wasted to such an extent that the insurance provided by the equity holders is inadequate to repay the creditors. There is no short-term panacea of the kind that resolves a pure liquidity problem. It can take a long time to determine whether institutions are insolvent, because it is necessary to revalue all the assets and liabilities in its balance sheet, and if insolvency is revealed it can take a long time to work through the ensuing problems and apportion losses. Delays in working through insolvencies can delay recovery from a crisis.

The real problems are manifested in the tangible legacy of the crisis. The legacy may be excess capacity in physical infrastructure - e.g. empty factories and offices, closed shops and half-built housing estates - or large but dysfunctional institutions - e.g. conglomerate firms formed through ill-considered mergers. Excess capacity and flawed institutions are often concentrated in the specific sectors that led the expansion during the preceding boom. Excess capacity after a crisis is not just the consequence of the crash itself but of the errors of judgement that led to it.

\section{Methodological issues}

The object of this chapter is to explain why crises occur and not to pass judgement on those involved in them. A causal explanation may well identify guilty parties, but 
learning lessons for the future is just as important as taking vengeance or demanding restitution for the past. This chapter does not therefore set out to condemn bankers, or others who profit from the capitalist system, but rather to explain why they behave the way they do.

A rigorous theory of crisis will explain why crises occur when they do, and why there is relative normality at other times. Most orthodox economic theories erroneously suggest that there will never be a crisis, but unorthodox theories often suggest that there will be perpetual crisis, and thereby fail to explain normality. Theory needs to explain both crisis and normality, and to identify the conditions that govern when the system switches (or 'tips') from one state to the other. Periods of normality tend to persist for longer than period of crisis, and the theory should explain this too.

To examine crises systemically, therefore, it is necessary to use periods of normality as a control. If a theory can successfully identify conditions conducive to normality, it should be able to derive, by exception, the conditions conducive to crisis (and vice versa). To implement this approach, however, it is necessary to have a rigorous definition of a crisis.

The focus of this chapter is a crisis of coordination in a capitalist economy (Lachmann, 1977). Wars and natural disasters can affect an economy, but the breakdown of the economic system is the focus here. Instability of market prices, defaults on contracts, insolvency of banks and firms, and the breakdown of institutions are the key symptoms of a coordination crisis. Governments as well as firms may become insolvent if they cannot raise sufficient taxes or loans, but this applies only in the most severe cases (De Bonis, Giustiniani and Gomel, 1999).

It is not only capitalism that is prone to crisis: crises can also affect planned economies - including socialist, communist and fascist ones. Failures of planned economies are usually attributed to over-centralisation. The same is also true of the failure of some empires and ancient civilisations; over-centralisation is blamed for a failure to adjust to adverse external conditions involving climate change, environmental degradation, or threats of invasion (Dark, 2001). As we shall see, however, over-centralisation can also occur in capitalist economies as a result of cultural conformity, and can lead to similar results.

Crises are normally unexpected - although prophetic figures may have issued warnings, these will typically have been ignored by the majority of people (Calomiris and Gorton, 1991). By the time a crisis is recognised, the course of events cannot normally be reversed. Policy is therefore defensive, with a focus on damage limitation. Crisis situations are often unstable - responses need to be urgent, because the more quickly remedial treatment is administered, the better are the chances of a recovery (Allen and Gale, 2000). In the long run, crises may generate opportunities for change - e.g. social and political improvements - but in the short run it is their negative aspects that predominate.

Prior to a crisis, people usually regard the situation as satisfactory and stable. They are not particularly alert to information, since they expect new information to confirm what they believe that they already know. They are happy to take advice because they see no reason to distrust it. Once a crisis develops, however, people recognise that 
they may have been wrong, and so they scrutinise information more thoroughly. They discover that promises have been broken and that contracts have been repudiated. Reputations are lost when people realise that they have been misled by people and institutions that they trusted. They lose confidence in their leaders, their professional advisors, and in the key institutions that these people control - banks, pension funds and businesses. Realising how little they actually knew about the situation before the crisis developed, rumours therefore become rife, and people react to snippets of information in a way that they would never do in more normal times (Kaminsky, Reinhart and Vegh, 2003).

Most countries have experienced a succession of crises involving weak regulation of banking and excessive speculation in land and property. To make the volume of evidence manageable, this chapter focuses on only the most serious crises. Almost all these crises all have a strong international dimension to them, and involve some form of innovation which fails to live up to expectations. As indicated earlier, many of these innovations are sponsored by governments as well as private firms.

Speed is widely recognised as important in profiting from innovations. Monopoly profits accrue to the first mover (unless their move is premature) and followers may achieve only the normal profits available under competition. But it is often difficult for rivals to know who has already moved, and there are many instances where competition to be first leads ultimately, and ironically, to excess capacity (Richardson, 1960). Governments too can profit from first mover advantage. An innovative country can enhance its political status and international influence, whilst the politicians that sponsor innovations may can advance their careers and increase their popularity.

The diffusion of innovations is potentially global, and is expedited when international trade is strong and political elites in different countries emulate each other. News of successful innovations travels fast, and investment fads are quickly replicated in other countries. Furthermore, international capital markets make it relatively easy to invest in innovations exported to other countries. Indeed, economic imperialism is predicated on this principle. Each imperial metropolis raises capital for overseas investment in its dependencies, and sets out to imitate the projects undertaken by its rivals.

Table 1 lists the major crises that have affected the UK over the last four hundred years. An appropriate point at which to begin is the Commercial Revolution that started in late Elizabethan England and continued under the Stuart dynasty, whilst the recent credit crunch makes a suitable finishing point. The table identifies seven subperiods, in each of which there was a distinctive political and business culture that legitimated certain types of innovation. The innovations were commended for conferring both private benefits for investors and social benefits for the country. The 'big idea' behind each type of innovation is identified in the left-hand column, together with the crises that developed as a result its uncritical implementation. The particular form of capitalism prevailing at the time is identified in the second column, while the institutional innovations in type of firm are set out in the third column. The international dimension is discussed in the right-hand column. The mid-points in time between successive crisis may be taken as indicative of the normality with which these crises are to be compared. 


\section{The economic analysis of crisis}

\section{Entrepreneurship}

This section sets out an economic theory of crises that explains the most obvious differences between crisis and normality in the cases identified above. It is based on the theory of entrepreneurship (for a survey see Casson, Yeung, Basu and Wadeson, 2006). It recognises explicitly that information is costly. Decisions have to be taken on the basis of incomplete information. Collecting all the information required to eliminate risk from any decision would be prohibitively costly. Mistakes are therefore inevitable. Mistakes are not necessarily irrational, however. A rational decision-maker facing information costs will deliberately economise on information. He will trade-off the cost of information against the reduction in risk that this information would provide. They will search for information in a systematic way, re-evaluating prospective information in the light of the latest information they have just received. They will stop their search for information at the point where the expected benefit from the next-most-valuable piece of information they could obtain is just equal to the cost of collecting it. According to this view, a rational agent runs a calculated risk of making mistakes. Making no mistakes at all would be inefficient because it would involve excessive expenditure on information.

\section{Decision-making with costly information}

Within this context the role of the entrepreneur is that of a specialist decision-maker. The classic entrepreneur establishes a firm in order to produce an innovative product, or exploit a new technology. This is risky because product demand is uncertain, the technology may have a hidden snag, and so on. Financial capital must be committed to buying or leasing plant and equipment and to hiring workers, and this investment cannot be recovered if the project fails. The entrepreneur therefore needs to feel confident that his judgement is right.

A free enterprise economy typically has many entrepreneurs. Sources of information are widely distributed in the economy, and as a result people differ in their perceptions of a situation. One person may believe that they have recognised an opportunity for innovation whereas another may not. If both parties are confident of their views then the optimist will seek funding and the pessimist will refuse to supply it. On the other hand, the pessimist will not compete with the optimist because he sees no profit in it, and so the optimist can achieve a temporary monopoly profit if he is right.

If an entrepreneur has limited reputation then he will have to fund most of start up himself. Family and friends may help, but everyone else will perceive high risk. The entrepreneur may approach a bank, but a traditional bank will be very cautious and may demand substantial collateral (such as a second mortgage) for a loan.

Entrepreneurs with limited reputation often runs small and medium-sized family businesses, or are involved in professional partnerships. Although such businesses may be adversely affected by crises, they are rarely implicated as causes of a crisis. They are too small and too carefully managed to create problems for the economy as a whole. 
A highly reputable entrepreneur is in a different position. People respect his judgement, so if he says there is an opportunity then some people will change their minds just because he says so. For a reputable entrepreneur, therefore, the problem is more one of finding projects to use the capital at his disposal than to find the capital for a chosen project. Indeed, successful entrepreneurs often develop into venture capitalists and merchant bankers because they have access to capital and develop an ability to evaluate other people's projects.

A highly reputable entrepreneur does not need to risk a lot of his own money in a venture. Other people's money is readily available. He may need to hold some equity in order to reassure people that he has a personal incentive to manage well, but he can take much of his reward as fees and salary. In some cases, indeed, he may simply act as an employee of the business he has founded, receiving share options and performance-related salary. He may even divide his time between several different businesses. A reputable entrepreneur can do a lot of damage if his reputation turns out to be unwarranted because of the size and range of businesses he controls. He may also get involved in promoting a particular type of innovation, and then founding businesses that appeal to people who wish to invest in it, as explained below.

\section{Fashions for sector-specific projects}

Sometimes reputation may be gained simply from the type of project to be undertaken. If a reputable person, such as a conspicuously successful entrepreneur, announces that a certain sector has exceptional growth prospects then unknown entrepreneurs in the sector will also find it easier to borrow funds. In this case, however, the monopoly model no longer applies, because the entrepreneurs are not battling against scepticism in the manner described above. Unless entrepreneurs can restrict entry through patents or powerful brands, they will not sustain even temporary monopoly profit.

Because of the localisation of information, entrepreneurs who invest in a fashionable sector may be unaware that others are doing the same. Although they are just following fashion, they may not realise this. It is often difficult for a person to be sure exactly where their own ideas come from, and there is a potential bias to believing that good ideas are entirely your own. If entrepreneurs in a sector announced their investment plans in advance they could, in principle, be coordinated, but as they often them keep secret to deter imitation, the unintended replication of investment projects may not come to light until too late (Richardson, 1960).

While a fashionable sector may well grow, competition means that the benefits will accrue mainly to customers (through price competition) and workers with specialist skills (through wage competition). Competition in product and factor markets will therefore subject entrepreneurs and their shareholders to a profits squeeze. In addition, failure to coordinate investments may result in long-run over-capacity.

\section{Opinion leadership}

There is also a risk that the opinion leader may be wrong in their assessment of the sector's prospects. Assessments of sectors are often based on ideologies as much as evidence (Casson, 2006). To people who believe that science holds the key to 
progress, a high-technology industry is a natural candidate as an innovative sector, whilst to those who believe in creativity and imagination, cultural and media industries are natural candidates too. Evidence on the potential of innovative sectors is often based on the performance of pioneering firms. Such evidence may be premature, however; success may prove short-lived and may depend on specific local factors that cannot be replicated throughout the sector as a whole.

Opinion leaders do not necessarily disseminate their views through the popular media. Opinions are often most influential when people believe that they are being let into a secret. Opinions can cascade through social networks (Bikhchandi, Hirschleifer and Welch, 1992). The opinion leader disseminates his opinions personally to members of his elite network, whose members in turn preside over networks of somewhat lower status. As the opinion cascades downward, each person hears it from someone they know personally who is of higher status than themselves. They are therefore inclined to trust it. Without an accurate mental model of how social networks are structured, they may fail to appreciate that the same opinion is cascading down through numerous other networks at the same time. As a result, they may believe that they have privileged access to this information relative to their peers. This makes them more likely to act upon the opinion because they perceive a greater potential profit from it than in fact exists.

A dishonest opinion leader may deliberately set out to exploit social networks for personal gain - making money for himself through a sophisticate form of pyramid selling. Honest opinions can disseminate in the same way, however; indeed, an honest-opinion leader may be unaware of the influence they possess because they too have a naïve view of social network structure and do not fully appreciate how their opinions will be used. The key point is not the at the leader is honest or dishonest but their opinion may ion fact be wrong.

\section{Degree of commitment}

Ordinary entrepreneurs may well be influenced by an opinion-leader. Others may recognise that a fad is developing, but still believe that they can profit from it - by devising projects purely to appeal to investors. High-commitment entrepreneurs will not do this, but low-commitment ones will. High-commitment entrepreneurs invest in projects designed to satisfy customer needs, and may even aim to benefit employees and society too. They normally plan to remain involved with their projects until they retire and to hand over to a worthy successor. They will be personally involved in ownership, and will bear their share of any losses should the projects fail. Lowcommitment entrepreneurs, on the other hand, develop projects purely as a means of extracting capital gains and management fees. Their projects are designed to satisfy the needs of investors seeking high returns. Not only do they plan to operate the project in a ruthless low-cost mode, but they plan to liquidate their own investment before the project is complete. When projects of this nature proliferate, the legacy of a crisis is not so much excess capacity as no capacity at all. The fraudulent nature of many business failures in fashionable sectors is well attested from contemporary documents, although allowance must be made for the atmosphere of recrimination at the time that many of these documents were produced. 
Exaggerated claims for the prospects of some innovative sector appear, from the evidence, to be a factor in many crises. The problem can be exacerbated in various ways.

- When people believe that a certain type of project is likely to be successful, 'due diligence' in appraisal is discouraged. Why invest in collecting detailed local information when such information will make no difference to the decision to proceed, and when finance is forthcoming on a relatively sketchy project brief? Not only does a project go ahead when it should not, but it is badly planned, and so produces worse results when it is completed. Lack of due diligence was a notable feature of some of the banking mergers and reorganisations that preceded (and followed) the recent crisis.

- The economy may be thought to be in danger of stagnating if it were not for innovation in the fashionable sector. This means that the innovative sector becomes 'the only show in town'. If there were a range of innovative sectors in which to invest then excessive investment in any one sector would be unlikely because of competition for funds. But when there is one fashionable sector and many unfashionable ones then the scope for excessive investment in the fashionable sector is much greater. The role of fashionable leading sectors is well attested in the historical literature, as is their role in booms and crises.

- Low-commitment entrepreneurs are most likely to thrive in an economy in which there are a significant number of people looking to gamble. Innovations in fashionable sectors may well be recognised as risky, but may still appeal to a particular type of investor. High profits appeal to people who aspire to enter a social elite and need the wealth to sustain their lifestyle. Such people believe they will be unhappy outside the elite, and very happy inside it, and therefore prefer a small chance of a big reward, that will get them into the elite, rather than a larger chance of a smaller reward, that will leave them better off but still outside. It is sometimes suggested that ambitious economic migrants fit this profile - particularly those who have been expelled from high status roles in other countries and wish to recover that status in their new home country.

\section{Speculation}

Entrepreneurs, as shown above, compete with each other in the exploitation of innovations. Each entrepreneur believes that their own innovation is unique, and will earn a monopoly profit. In effect, the entrepreneur speculates against his critics by proceeding with an innovation that they will not support. He is sufficiently selfconfident to believe that he is right and they are wrong. Opinions differ, because they are based on different sets local knowledge. This is a normal state for a private enterprise economy.

The notion that opinions differ, and can happily coexist, is reflected in a wide range of institutions in a free-enterprise economy, including a democratic political system, where rival ideologies co-exist, religious toleration, where rival belief systems coexist, and a legal system where disputes are resulted purely on the basis of factual evidence and legal rules rather than by reference to contested moral principles.

There are other ways of using local knowledge and backing one's judgement in order to make a profit. The most important is stock market speculation. Here the 
entrepreneur's judgement applies not to starting a business but to valuing businesses that have already established by other people. A speculator aims to make a capital gain by buying and re-selling ahead of market trends. A speculator buys shares in a firm they consider undervalued and re-sells at a profit when the shares are re-valued. Speculation can be based on fundamentals or on market sentiment (Shiller, 2000). Speculation based on fundamental principles is analogous to high-commitment entrepreneurship as described above, although applied to financial assets rather than real ones. The speculator believes that he has better information on the value of the firm than other people, and that the firm is actually more valuable than others think. When the truth is publicly revealed the speculator sells out and pockets his gain. Speculating on sentiment, however, is more akin to low-commitment entrepreneurship. The skill is to anticipate what other people will believe rather than to estimate what an asset is really worth. The speculator buys when he predicts that sentiment is moving in favour of the asset; he believes that other people will receive information which they will construe (rightly or wrongly) as indicating higher value. In some cases, this could be information that he himself has acquired, and has delayed releasing whilst he takes a position on the market. He buys when he realises that the information is about to appear and sells once it has done so.

Speculation of this kind can have real effects because when share prices rises it is easier for the firm concerned to raise new capital in order to finance investment. A fad for shares in a particular sector will therefore stimulate investment in the sector by reducing the cost of capital relative to other sectors. Promoting fads is a useful way for speculators in sentiment to engineer profits. Since such speculators often lack reputation (for obvious reasons), it is useful for them to have accomplices in journalism and the media, in order to cloak their information with respectability.

\section{The subjectivity of wealth}

In conventional economic models wealth is usually treated as objective, but in fact it is a highly subjective concept because the value of wealth depends crucially on expectations of the future. As expectations are revised so the value of wealth changes without any change in its physical composition. The fads and fashions associated with innovative sectors affect not only share prices in those sectors, but also the expected lifetime earnings of the people employed in them. A person's self-evaluation of their wealth (including unrealised capital gains that they expect to make on speculative investments) influence their consumption decisions - not only how much they consume, but also their choice of products. Talking up the prospects for a sector can raise subjective wealth and change consumption habits (including lifestyle choices). This may stimulate a consumer boom based on luxury products purchased out of higher profits and higher earnings. This in turn may stimulate investment in housing, retailing and leisure facilities - investments which appears excessive in the aftermath of crisis when subjective wealth has returned to more realistic levels.

High subjective wealth also encourages borrowing. Many individuals, for example, may wish to consume immediately out of future earnings through increased use of consumer credit, while firms in expanding sectors may borrow instead of reinvesting earnings. The more confident people are about their estimated wealth, the more likely they are to borrow at fixed interest. The greater the burden of fixed interest, the more 
likely is insolvency later on. Thus there is a direct connection between the degree of confidence before a crisis and the risk of bankruptcy afterwards.

While consumers may not be directly influenced by investment opportunities in the fashionable sector, they will be well aware of the fashion. The emergence of 'new money' in the sector, and of entrepreneurial role models featured in the media, will help them to appreciate where new wealth is supposedly being generated. Politicians are likely to get in on the act too. Business interests in the fashionable sector will lobby for tax breaks, and politicians will be keen to be seen to be supporting it. The more glamorous and exotic the product, the more support the sector is likely to get. The ideology of progress through science and creativity may also have political resonance and be used to reinforce partisan political rhetoric.

Political support for the innovative sector reinforces the distortion of investment. The leading firms may perceive themselves as national champions that cannot be allowed to fail. Should excess capacity emerge they believe that they will be able to lobby for protection, rationalisation or subsidy. By capping downside risk it stimulates additional investment.

The cumulative effect of these forces is to unite a business and political elite behind the fashionable sector. This creates an abnormal economic situation. Diversity of opinion, which secular liberal institutions are designed to protect, is no longer tolerated if it involves public criticism of the fashionable sector. Critics and whistleblowers of the sector find themselves ostracised by the elite. If they are influential they may find their personal reputation under attack. The suppression of relevant information helps to disguise emerging problems. Problems of potential insolvency are dismissed as temporary liquidity problems until they eventually become impossible to hide.

By this stage the crisis has become a financial crisis, rather than just a crisis of excessive investment, and in the ensuing panic the origins of the crisis are lost from view. The banks take the blame for having extended credit unwisely to the fashionable sector, and to other sectors that have benefited from the associated consumer boom. This lets of the hook the entrepreneurs who invested so unwisely, as they appear as victims of the financial system like everyone else. Politicians too can lay some of the blame on the banking system, although they often pay the price of failure later through the political process.

The implications of this analysis are summarised in Table 2.

\section{The international dimension}

Most UK crises have an international dimension, as Table 1 indicates. This partly reflects the openness of the economy, and the historical role of imperialism. The international dimension of crises is often used to suggest that crises originate outside the UK and are imported through international capital markets. The evidence suggests, however, that it is UK investments and political involvement in other countries that has often generated crises in the UK. 
For the past four hundred years, the international economy has expanded almost continuously, interrupted only by wars, protectionism, and recurrent crises. This expansion has been sustained by a continuous extension of the international division of labour (Wallerstein, 1979). New discoveries result in new products, which are produced using increasingly specialised assets, operated by specialised workers and managed by professional experts. The coordination of many such specialised activities is a major challenge, and specialised institutions, such as multinational firms and international banks, have emerged to fulfil this role.

Progress in the division of labour is not the product of random experimentation or myopic change, but of purposeful activity. Opportunities to advance the division of labour are recognised by entrepreneurs, who deliberately set out to find better ways of doing things. Inventions and discoveries result from these efforts. In some cases the effort may be motivated by a search for profit, or for status and celebrity, but public benefit may also be a motive too. Crises have developed when these efforts have been over-extended in the context of certain sectors.

The main problems have been

- The product or technology exploited by UK firms is fundamentally flawed, so that snags emerge when production is scaled up. Early chartered trading companies often failed because of low agricultural productivity, and schemes had to aborted before local infrastructure could be built (Darien, South Sea and Mississippi 'bubble' schemes)

- The technology, though successful, is quickly superseded by a superior one. This is may precipitate a crisis because of the large amount of investment that has been sunk, and the shortness of the effective pay-back period (tramways superseded by buses; gas lighting and hydraulic power superseded by electricity).

- Unexpected interruptions of supply due to war, expropriation of resources or supplier cartels may push up costs to prohibitive levels. (Imperial war defeats, Korean war, Oil price shock; decolonisation)

- The technology may lack local political or social support. The host government may refuse to make investments in infrastructure - e.g. transport, communication, power supplies - that are necessary for the technology to flourish. Foreign ownership of the technology, or its environmental impact, may become a political issue. Threats to traditional working practices, and resistance to job loses in competing traditional industries, may lead to strikes and popular protest. (Baring Crisis)

- The product or technology may be perfectly sound, but early enthusiasm may lead to excess supply. Failure to coordinate start-up investments may lead to excess capacity as each firm attempts to pre-empt rival entrants and fails. Enthusiasm may be fostered by strong early demand stimulated by fashion and novelty which soon wears off (Tulip Mania, Railway Mania, dot.com bubble)

Even where the product or technology is sound, failures can still emerge if project coordination is weak. The progressive expansion of the international labour raises a host of management challenges. Poor planning was blamed for the failure of many of the early overseas settlement schemes. As the supply chains controlled by firms have become increasingly complex, so management structures have evolved - typically by replacing hierarchical systems controlled by autocratic managers with 'flatter' and 
more flexible systems administered using a more consultative approach. These changes have often lagged the challenges, however, and managing complex systems using managerial systems that are legacies of an earlier and simpler age has been a regular cause of failure.

\section{Case study}

Case studies illustrate how a detailed analysis of crises can be carried out. This section summarises a case study of the UK Railway Mania. Table 1 listed major UK crises and Table 2 identified key aspects of these crises that can be explained by entrepreneurial failure. Railways represented a radical innovation (Schumpeter, 1939); main line passenger railways were pioneered in the UK, and quickly spread to the US, continental Europe and European colonies in Asia, Africa and the Pacific. When the UK Railway Mania collapsed in 1846 many investors were ruined, and it took many years to complete the building of lines authorised in that year. Investment in railways did not recover until 1860 (Casson, 2009).

Main line railways replaced canals, providing faster and more reliable transport. Canals had been highly profitable until the railways arrived, and many canal proprietors lost money from railway competition. Some canal proprietors sold out to railway companies, who closed their canals down to stifle potential rivalry. Railway proprietors, quite rightly, did not fear immediate competition from motor cars or aircraft, but they mistakenly ignored the threat of over-capacity on the railway system itself. They wrongly assumed that the railway schemes in which they invested would become local monopolies.

The build up to the Mania began about 1842, when interest were low and the early main lines that had already been completed 1830-40 were earning good profits. Towns served by railways were booming, but towns that were by-passed were declining. Over-supply arose because every town wanted to be served by a railway so that it could share in the prosperity and avoid decline. Numerous railway schemes were laid before Parliament and to achieve popularity Parliament approved nearly all of them - far too many to be financed or constructed at any one time. Crucially, for almost every scheme that was authorised, one or two competing schemes were authorised as well, so that all hope of monopoly profit disappeared. Many investors wanted their money back, although much of it had already been spent on engineers' and lawyers' fees. The wealth that everyone anticipated also disappeared, and those that had borrowed against that wealth went bankrupt. There was no financial meltdown, however, because railway finance was based mainly on equity rather than debentures. Interest rates went up, but the banking system remained stable.

Many railway investors were relatively inexperienced. They underestimated network externalities on the railway system. They expected other lines to feed traffic onto their own line, but they did not expect competing lines to take traffic away. Politicians made matters worse; instead of wisely checking speculation, they encouraged it by backing high-risk schemes like Brunel's broad gauge. The collapse of the Mania destroyed confidence, and led to a reaction whereby even worthwhile schemes could not get financed. Many schemes that had been authorised were not built until many years later (some never at all). Demand for construction work dried up, and consumers stopped spending because they suddenly realised that they were much 
poorer than they had thought. The economy began to recover after a couple of years, but railway investment did not recover fully for almost twenty years. History then repeated itself, and a Second Railway Mania of the 1860s culminated in the dramatic Overend Gurney banking collapse of 1866. Once again the banking system as a whole survived, but investor confidence was destroyed, exactly as before.

The experience of the Railway Mania corroborates the view that political elites will often jump on popular bandwagons rather than stifle speculation and 'spoil the party'. At the time of the Mania railway technology was still developing, and network economies were not properly understood. Politicians ignored expert advice and followed popular sentiment in authorising large numbers of competing schemes. In the aftermath of the Mania they found convenient scapegoats in social outsiders, such as George Hudson, the 'railway king'. They quickly turned their attention away from railways, which had become a tainted topic, and re-focused on the Corn Laws and the Irish potato famine instead.

\section{Implications for business and economic history}

This chapter has outlined an economic model of crisis that is different from the usual type of economic model. Unlike many cliometric models that are based on conventional theory, it does not assume perfect information and efficiency. Instead it allows for mistakes. It suggests that the frequency of mistakes increases when the business and political elite become obsessed with the idea of promoting investment is some fashionable innovative sector. This strategy is seen by the elite as an antidote to potential stagnation in traditional sectors, and providing an opportunity for profitable stock market speculation. It also allows politicians to claim to have some sort of strategic plan for growth. The model can be tested by comparing clearly identified periods of build up to crisis with a control groups of normal situations. There is a series of dimensions along which the comparisons can be made. Although there are other theories of crisis, many of them are not easily testable because they either imply a continuous state of crisis, or cannot clearly identify the antecedents of crisis.

Furthermore, these theories tend to focus on the financial indicators of crisis, most of which appear only after the underlying problem has already developed. They therefore tend to look at symptoms rather to causes and to get their timing wrong.

To test the theory set out in this chapter it is necessary to combine information at different levels of aggregation. In contrast to conventional approaches, purely macroeconomic indicators are of limited significance. Investment, profits and share prices, for example, all need to be analysed at the sectoral level. Patterns of innovation need to be studied, together with the formation of firms. The histories of pioneering firms need to be investigated, and even biographies of leading entrepreneurs. Links between business, finance and government, and lobbying within elites, need to be explored in detail. The only way to implement this strategy is through a synthesis of the sources and methods of business history. Quantitative and qualitative analysis need to be combined - not in the form of thick description, but rather as a rigorous test of theory. 


\section{References}

Allen, Franklin and Douglas Gale (2000) Bubbles and Crises, Economic Journal, 110 (460) 236-255

Bernanke, Ben and Harold James (1991) The Gold Standard, deflation and financial crises in the Great Depression: An international comparison, in R. Glenn Hubbard (ed.), Financial Markets and Financial Crises, Chicago: University of Chicago Press for the National Bureau of Economic Research, 33-68

Bikhchandi, Sushil, David Hirschleifer and Ivo Welch (1992) A theory of fads, fashion, custom and cultural change as information cascades, Journal of Political Economy, 100 (5), 992-1026

Calomiris, Charles W. and Gary Gorton (1991) The origin of banking panics: Models, Facts and Bank Regulation, in R. Glenn Hubbard (ed.), Financial Markets and Financial Crises, Chicago: University of Chicago Press for the National Bureau of Economic Research, 109-174

Campbell, Gareth (2009) The Dividend Mania: Stock prices and dividends during the Railway Mania, Chapter presented at the Economic History Society Annual Conference, Warwick, April

Carswell, John (1960) The South Sea Bubble, London: Cresset Press

Casson, Mark C. (2006) Culture and economic performance, in David Throsby and Victor Ginsburgh (eds.) Handbook of the Economics of Culture and the Arts, Amsterdam: North-Holland, 359-398.

Casson, Mark C., B. Yeung, A. Basu and N. Wadeson (eds.) (2006) Oxford Handbook of Entrepreneurship, Oxford: Oxford University Press

Casson, Mark C. (2009) The World's First Railway System, Oxford: Oxford University Press

Dale, Richard S., Johnnie E.V. Johnson and Leilei Tang (2005) Financial markets can go mad: evidence of irrational behaviour during the South Sea Bubble, Economic History Review, 58 (2), 233-271

Dark, K.R.(1998) Waves of Time: Long-term Change and International Relations, London: Pinter

Dash, Mike (1999) Tulipomania: The Story of the World's Most coveted Flower and the Extraordinary Passions it Aroused, London: Gollancz

De Bonis, Roccardo, Alessandro Giustiniani and Giorgio Gomel (1999) Crises and bail-outs of banks and countries: Linkages, analogies and differences, World Economy, 22 (1), 55-86 
Eichengreen, Barry (1997) The Baring Crisis in a Mexican Mirror, International Political Science Review, 20 (3) 249-270

Elliott, Geoffrey (2006) The Mystery of Overend \& Gurney: A Financial Scandal in Victorian London, London: Methuen

Fishlow, Albert (1985) Lessons from the past: Capital markets during the nineteenth century and the Interwar period, International Organization, 39 (3), 383-439

Freixas, Xavier, Curzio Giannini, Glenn Hogarth and Farouk Soussa (1999) Lender of last resort: A review of the literature, Bank of England Financial Stability Review, 7, November, 151-167

Ferguson, Niall and Moritz Schularick (2006) The Empire effect: The determinants of country risk in the first Age of Globalisation, 1880-1913, Journal of Economic History, 66 (2), 283-312

Flores, Juan-Huiyzi (c.2002) A microeconomic analysis of the baring Crisis, 18801890, Madrid: Universidad Carlos III de Madrid

Garber, Peter (2001) Famous First Bubbles: The Fundamentals of Early Manias, Cambridge, MA: MIT Press

Garside, W.R. (2007) The Great Depression, 1929-1933, Economic Disasters of the Twentieth Century, Cheltenham: Edwad Elgar, 51-82

Gertler, Mark, R. Glenn Hubbard and Anil Kashyap (1991) Interest rate spreads, credit constraints and investment fluctuations: An empirical investigation, in R. Glenn Hubbard (ed.), Financial Markets and Financial Crises, Chicago: University of Chicago Press for the National Bureau of Economic Research, 11-32

Goldgar, Anne (2007) Tulipmania: Money, Honour and Knowledge in the Dutch Golden Age, Chicago: University of Chicago Press

Hayek, Friedrich A. (1933) Monetary Theory and the Trade Cycle (trans. N. Kaldor) London: Jonathan Cape

Insch, George Pratt (1947) The Darien Scheme, London: Historical Association

Kaminsky, Graciela, Carmen M. Reinhart and Carlos A. Vegh (2003) The unholy Trinity of financial contagion, Journal of Economic Perspectives, 17 (4), 51-74

Kindleberger, Charles P. (1978) Manias, Panics and Crashes: A History of Financial Crises, New York: Basic Books

Lachmann, Ludwig (1977) Capital, Expectations and the Market Process: Essays on the Theory of the Market Economy (ed. Walter E. Grinder) Kansas City: Sheed, Andrews McMeel 
Mackay, Charles (1841) Extraordinary Popular Delusions and the Madness of Crowds [London: R. Bentley, 1841], New ed. with introduction by John Marks Templeton, Philadelphia, PA: Templeton Foundation Press, 1995

Marglin, Stephen A. and Julia Schorr (eds.) (1990) The Golden Age of Capitalism: Reinterpreting the Postwar Experience, Oxford: Oxford University Press

Marichal, Carlos (1989) A Century of Debt Crises in Latin America; From Independence to the Great Depression, 1820-1930, Princeton, NJ: Princeton University Press

Maroney, Neal, Atsuyuki Naka and Theresia Wansi (2004) Changing risk, return and leverage: The 1997 Asian financial crisis, Journal of Financial and Quantitative Analysis, 39 (1), 143-166

Michie, Ranald C. (1985) The London Stock Exchange and the British Securities Market, 1850-1914, Economic History Review, 38 (1), 61-82

Mitchener, Kris James and Marc D. Weidenmier (2006) The Baring Crisis and the Great Latin American Meltdown of the 1890s, Santa Clara, CA: Santa Clara University

Mishkin, Frederic S. (1991) Asymmetric information and financial crises, in R. Glenn Hubbard (ed.) Financial Markets and Financial Crises, Chicago: University of Chicago Press, 69-101

Narian, Aditya, Inci Otker and Ceyla Pazarbasiglu (2012) Building a More Resilient Financial Sector, Washington, DC: International Monetary Fund

Neal, Larry (1998) The financial crisis of 1825 and th restructuring of the British financial system, Federal Reserve Bank of St. Louis Review, May/June, 53-76

Oliver, Michael J. (2007) Financial Crises, in Michael J. Oliver and Derek H. Aldcroft (ed.), Economic Disasters of the Twentieth Century, Cheltenham: Edward Elgar, 182235

Palma, Gabriel (2003) The 'Three routes to financial crises: Chile, Mexico and Argentina; Brazil; and Korea, Malaysia and Thailand, in Ha-Joon Chang (ed.)

Rethinking Development Economics, London: Anthem Press, 347-76

Radlett, Steven and Jeffrey D. Sachs, (1998) The East Asian Financial Crisis: Diagnosis, Remedies and prospects, Brookings Chapters on Economic Activity, 1, 179

Richardson, George B. (1960) Information and Investment: A Study in the Working of the Competitive Economy, Oxford: Oxford University Press

Rothbard, Murray N. (1962) The Panic of 1819: Reactions and Policies, New York: Columbia University Press 
Schumpeter, Joseph (1939) Business Cycles: A Theoretical, Historical and Statistical Analysis of the Capitalist Process, New York: McGraw Hill

Shiller, Robert J. (2000) Irrational Exuberance, Princeton: Princeton University Press

Wallerstein, Immanuel M. (1979) The Capitalist World Economy: Essays, Cambridge: Cambridge University Press

Wood, Christopher (1992) The Bubble Economy: The Japanese Economic Collapse, London: Sidgwick \& Jackson

Wood, John Philip (1824) Memoirs of the Life of John Law of Lauriston; Including a Detailed Account of the Rise, Progress and Termination of the Mississippi System, Edinburgh: A. Black 
Table 1: Crises originating in or impacting upon the UK, 1600-2007

\begin{tabular}{|c|c|c|c|c|}
\hline Dates & Events & $\begin{array}{l}\text { Type of } \\
\text { capitalism }\end{array}$ & $\begin{array}{l}\text { Institutional } \\
\text { characteristics of } \\
\text { firms }\end{array}$ & $\begin{array}{l}\text { International } \\
\text { business } \\
\text { operations } \\
\end{array}$ \\
\hline $\begin{array}{l}1600- \\
1760\end{array}$ & $\begin{array}{l}\text { Big idea: trade } \\
\text { expansion } \\
\text { Internal: } \\
\text { Darien Scheme, } \\
\text { 1695, } \\
\text { South Sea Bubble, } \\
1711 \\
\\
\text { External: Dutch } \\
\text { Tulip Mania, 1637, } \\
\text { French Mississippi } \\
\text { Company Bubble, } \\
1719\end{array}$ & $\begin{array}{l}\text { Proprietary } \\
\text { capitalism } \\
\text { based on natural } \\
\text { products. } \\
\text { Speculative } \\
\text { mines and } \\
\text { plantations }\end{array}$ & $\begin{array}{l}\text { Partnerships, family } \\
\text { firms } \\
\text { Local market served } \\
\text { mainly by single-plant } \\
\text { firms } \\
\text { Formation of chartered } \\
\text { joint-stock companies, } \\
\text { e.g. East India } \\
\text { Company, 1600, } \\
\text { Hudson Bay Company, } \\
1670\end{array}$ & $\begin{array}{l}\text { Trade through } \\
\text { mercantile } \\
\text { partnerships } \\
\text { involving } \\
\text { overseas } \\
\text { agencies. Some } \\
\text { wholly-owned } \\
\text { trading posts }\end{array}$ \\
\hline $\begin{array}{l}1760- \\
1840\end{array}$ & $\begin{array}{l}\text { Big idea: Industrial } \\
\text { expansion } \\
\text { Internal: } \\
\text { Banking Crisis, } \\
1825 \\
\\
\text { External: US } \\
\text { Panics of } 1819 \text { and } \\
1837\end{array}$ & $\begin{array}{l}\text { Proprietary } \\
\text { capitalism } \\
\text { based on } \\
\text { factory-made } \\
\text { products }\end{array}$ & $\begin{array}{l}\text { Partnerships, family } \\
\text { firms. } \\
\text { National markets } \\
\text { served by large } \\
\text { factories making } \\
\text { textiles, pottery, metal } \\
\text { goods. Distribution by } \\
\text { canal and turnpike } \\
\text { roads }\end{array}$ & $\begin{array}{l}\text { Imports of raw } \\
\text { materials and } \\
\text { exports of } \\
\text { finished goods } \\
\text { through } \\
\text { mercantile } \\
\text { partnerships, with } \\
\text { some direct } \\
\text { export by } \\
\text { manufacturers }\end{array}$ \\
\hline $\begin{array}{l}1840 \\
- \\
1890\end{array}$ & $\begin{array}{l}\text { Big idea: } \\
\text { Infrastructure } \\
\text { projects for } \\
\text { national and } \\
\text { colonial } \\
\text { development } \\
\text { Internal; } \\
\text { Railway Manias, } \\
\text { 1844-46, 1860-66 } \\
\text { Overend Gurney } \\
\text { Crisis, 1866, } \\
\\
\text { External: } \\
\text { Disruption of trade } \\
\text { by the American } \\
\text { Civil War, 1861-65 }\end{array}$ & $\begin{array}{l}\text { Metropolitan } \\
\text { capitalism } \\
\text { based on large } \\
\text { joint stock } \\
\text { companies } \\
\text { financed } \\
\text { through stock } \\
\text { exchanges. } \\
\text { Infrastructure } \\
\text { projects } \\
\text { improve } \\
\text { transport } \\
\text { (railways, } \\
\text { harbours), } \\
\text { communi- } \\
\text { cations }\end{array}$ & $\begin{array}{l}\text { Large joint-stock } \\
\text { national firms expand } \\
\text { through acquisition of } \\
\text { local and regional } \\
\text { firms. Active } \\
\text { shareholder } \\
\text { participation. } \\
\text { Growth of patents, } \\
\text { trademarks, and } \\
\text { advertising in national } \\
\text { press. } \\
\text { Professional railway } \\
\text { management evolves, } \\
\text { based on the military } \\
\text { model of an 'officer } \\
\text { class' }\end{array}$ & $\begin{array}{l}\text { Free-standing } \\
\text { companies make } \\
\text { project-based } \\
\text { investments in } \\
\text { developing } \\
\text { countries, e.g. } \\
\text { Latin America, } \\
\text { Australia, Asia. } \\
\text { Directors are } \\
\text { based in the } \\
\text { metropolis and } \\
\text { managers } \\
\text { overseas. } \\
\text { Extensive use of } \\
\text { metropolitan } \\
\text { engineering }\end{array}$ \\
\hline
\end{tabular}




\begin{tabular}{|c|c|c|c|c|}
\hline & & $\begin{array}{l}\text { (telegraph), and } \\
\text { urban quality of } \\
\text { life (lighting, } \\
\text { gas supply) }\end{array}$ & & $\begin{array}{l}\text { consultancies, } \\
\text { lawyers and } \\
\text { stock-brokers }\end{array}$ \\
\hline $\begin{array}{l}1890 \\
-1914\end{array}$ & $\begin{array}{l}\text { Big idea: London } \\
\text { as a centre of } \\
\text { international } \\
\text { finance } \\
\text { External: } \\
\text { Mexican 'Baring } \\
\text { Crisis', } 1890 \\
\text { Wars of imperial } \\
\text { expansion; } \\
\text { occasional defeats }\end{array}$ & $\begin{array}{l}\text { Anti-capitalism: } \\
\text { Social } \\
\text { reformers, trade } \\
\text { unionists and } \\
\text { feminists } \\
\text { challenge the } \\
\text { inequalities } \\
\text { attributed to } \\
\text { monopoly } \\
\text { capitalism. } \\
\text { Some promote } \\
\text { revolution } \\
\text { whilst other } \\
\text { wish to pre- } \\
\text { empt it. }\end{array}$ & $\begin{array}{l}\text { Merger and trust } \\
\text { movements create large } \\
\text { monopolistic firms. } \\
\text { Aristocratic directors } \\
\text { represent shareholder } \\
\text { interests, and } \\
\text { shareholder activism } \\
\text { declines. } \\
\text { Countervailing growth } \\
\text { of large 'stakeholder' } \\
\text { enterprises: mutuals } \\
\text { (building societies), } \\
\text { consumer co-operatives } \\
\text { (retailers), employee- } \\
\text { owned firms and } \\
\text { paternalistic family } \\
\text { firms (food processors } \\
\text { and retailers) }\end{array}$ & $\begin{array}{l}\text { High-imperialist } \\
\text { European race for } \\
\text { Africa. } \\
\text { Government } \\
\text { sponsorship of } \\
\text { large companies } \\
\text { dedicated to } \\
\text { exploiting } \\
\text { resources in } \\
\text { conquered } \\
\text { territories. }\end{array}$ \\
\hline $\begin{array}{l}1914- \\
1945\end{array}$ & $\begin{array}{l}\text { Big idea: Social } \\
\text { justice in the } \\
\text { workplace } \\
\text { Internal: } \\
\text { Decline of textiles } \\
\text { and engineering, } \\
1921 \\
\\
\text { External: } \\
\text { Wall Street Crash } \\
\text { \& Great Depression } \\
\text { 1929-33 }\end{array}$ & $\begin{array}{l}\text { Regulated } \\
\text { managerial } \\
\text { capitalism: } \\
\text { National } \\
\text { champions are } \\
\text { created through } \\
\text { rationalisation } \\
\text { movements in } \\
\text { declining or } \\
\text { under- } \\
\text { performing } \\
\text { industries (e.g. } \\
\text { textiles, } \\
\text { chemicals) }\end{array}$ & $\begin{array}{l}\text { Protected national } \\
\text { markets reduce } \\
\text { international division } \\
\text { of labour. } \\
\text { Military anxieties } \\
\text { stimulate defence- } \\
\text { related R\&D. } \\
\text { Managers emulate war- } \\
\text { time planners in } \\
\text { centralising control } \\
\text { within hierarchies. } \\
\text { State offers subsidies to } \\
\text { induce compliance with } \\
\text { regulation. }\end{array}$ & $\begin{array}{l}\text { Political risks of } \\
\text { foreign } \\
\text { investment } \\
\text { increase. } \\
\text { International } \\
\text { cross-licensing } \\
\text { and patent pools } \\
\text { develop, } \\
\text { involving national } \\
\text { champions from } \\
\text { different } \\
\text { countries }\end{array}$ \\
\hline $\begin{array}{l}1945- \\
1976\end{array}$ & $\begin{array}{l}\text { Big idea: } \\
\text { Consumerism } \\
\text { Internal: } \\
\text { IMF Crisis of 1976, } \\
\text { caused by high } \\
\text { public expenditure, } \\
\text { strikes and Asian } \\
\text { competition }\end{array}$ & $\begin{array}{l}\text { Welfare } \\
\text { Capitalism: The } \\
\text { 'Golden Age of } \\
\text { Western } \\
\text { Growth'. } \\
\text { Managerial } \\
\text { capitalism with } \\
\text { passive } \\
\text { shareholders. } \\
\text { Firms sacrifice } \\
\text { profits to link } \\
\text { with big } \\
\text { government and } \\
\text { trades unions in }\end{array}$ & $\begin{array}{l}\text { Managerial rewards } \\
\text { based on salaries } \\
\text { related to size of firm, } \\
\text { encouraging low-risk } \\
\text { high-growth strategies. } \\
\text { Firms grow } \\
\text { domestically through } \\
\text { regional and industrial } \\
\text { diversification. } \\
\text { High income tax rates } \\
\text { encourage lavish } \\
\text { expensive accounts } \\
\text { Firms grow } \\
\text { domestically through }\end{array}$ & $\begin{array}{l}\text { US hegemony } \\
\text { reduces political } \\
\text { risks for Western } \\
\text { foreign investors. } \\
\text { Commercial- } \\
\text { isation of wartime } \\
\text { R\&D encourages } \\
\text { high-technology } \\
\text { foreign direct } \\
\text { investment by US } \\
\text { firms, using a } \\
\text { hierarchical } \\
\text { headquarters - } \\
\text { foreign subsidiary }\end{array}$ \\
\hline
\end{tabular}




\begin{tabular}{|c|c|c|c|c|}
\hline & & $\begin{array}{l}\text { pursuit of a } \\
\text { Welfare Sate }\end{array}$ & $\begin{array}{l}\text { regional and industrial } \\
\text { diversification }\end{array}$ & $\begin{array}{l}\text { structure. } \\
\text { Weak intellectual } \\
\text { property rights } \\
\text { discourage } \\
\text { licensing; foreign } \\
\text { direct investment } \\
\text { is preferred where } \\
\text { political risks are } \\
\text { low }\end{array}$ \\
\hline $\begin{array}{l}1973- \\
2007\end{array}$ & $\begin{array}{l}\text { Big idea: } \\
\text { Competition and } \\
\text { incentives } \\
\text { Internal: } \\
\text { Housing market } \\
\text { crisis, 1972, Dot- } \\
\text { com Bubble,1998- } \\
2000 \\
\text { Credit crunch, } 2007 \\
\text { External: } \\
\text { Oil price shocks, } \\
\text { 1973, 1979 } \\
\text { Asian financial } \\
\text { crisis, } 1997\end{array}$ & $\begin{array}{l}\text { Bonus } \\
\text { capitalism: } \\
\text { Shareholder } \\
\text { rights, } \\
\text { management } \\
\text { incentives. } \\
\text { Asian } \\
\text { competition } \\
\text { initiates radical } \\
\text { policy response. } \\
\text { Keynesianism } \\
\text { abandoned in } \\
\text { favour of free } \\
\text { markets and } \\
\text { monetarism. }\end{array}$ & $\begin{array}{l}\text { Decline of national } \\
\text { champions due to low } \\
\text { labour productivity and } \\
\text { unrelated } \\
\text { diversifications } \\
\text { encourages growth of } \\
\text { small proprietary firms } \\
\text { through management } \\
\text { buy-outs and start-ups } \\
\text { by redundant } \\
\text { employees. } \\
\text { Privatisation of } \\
\text { national and municipal } \\
\text { enterprises. } \\
\text { Dominant shareholders } \\
\text { such as pension funds } \\
\text { become more active. } \\
\text { Managers are } \\
\text { encouraged to take } \\
\text { calculated risks by } \\
\text { relating their rewards to } \\
\text { share price and profits } \\
\text { through bonuses and } \\
\text { stock options. } \\
\text { Hostile take-overs } \\
\text { promote a market in } \\
\text { managerial control. }\end{array}$ & $\begin{array}{l}\text { Globalisation of } \\
\text { product markets: } \\
\text { tariff reductions, } \\
\text { container } \\
\text { shipping, jet } \\
\text { travel and } \\
\text { motorways } \\
\text { reduce barriers to } \\
\text { trade. } \\
\text { Globalisation of } \\
\text { capital markets: } \\
\text { internet } \\
\text { communications, } \\
\text { removal of } \\
\text { exchange controls } \\
\text { and 'light touch' } \\
\text { banking } \\
\text { regulation } \\
\text { liberalise capital } \\
\text { markets. } \\
\text { Stronger } \\
\text { intellectual } \\
\text { property rights } \\
\text { encourage } \\
\text { licensing, joint } \\
\text { ventures, etc. } \\
\text { Resultant out- } \\
\text { sourcing and off- } \\
\text { shoring create } \\
\text { 'hollowed out' or } \\
\text { 'flagship' } \\
\text { multinationals. }\end{array}$ \\
\hline
\end{tabular}

Sources: Bernanke and James (1991), Campbell (2009), Carswell (1960), Dale, Johnson and Rang (2005), Dash (2001), Eichengreen (1997), Elliott (2006), Fishlow (1985), Freixas, Giannibni, Hogarth and Soussa (1999), Ferguson and Schularick (2006), Flores (2002), Garber (2001), Garside (2007), Goldgar (2007), Insch (1947), Marglin and Schor (1990), Marichal (1989), Maroney, Naka and Wansi (2004), Michie (19850, Mitchener and Weidenmier (2006), Neal (1998), Oliver (2007), Palma (2003), Radlett and Sachs (1998), Rothbard, 1962, Wood (1992), Wood (1824). 
Table 2

Simple typology of the normal state of the economy and a crisis-prone state

\begin{tabular}{|c|c|c|}
\hline Issue & Normality & Crisis build-up \\
\hline Innovation & Incremental & Radical \\
\hline Sources of information & Diverse and local & Judgements of a new elite \\
\hline Sector & Diversified & $\begin{array}{l}\text { One fashionable sector and } \\
\text { many unfashionable ones }\end{array}$ \\
\hline Profits & $\begin{array}{l}\text { Numerous small } \\
\text { temporary monopolies } \\
\text { eroded by imitation }\end{array}$ & $\begin{array}{l}\text { Simultaneous } \\
\text { uncoordinated large } \\
\text { investments }\end{array}$ \\
\hline Style of investment & $\begin{array}{l}\text { High-commitment; } \\
\text { customer focus; no plan to } \\
\text { sell out }\end{array}$ & $\begin{array}{l}\text { Low-commitment; } \\
\text { investor focus; plan to sell } \\
\text { out }\end{array}$ \\
\hline Style of management & $\begin{array}{l}\text { Varied: autocratic, } \\
\text { consultative, bureaucratic }\end{array}$ & Charismatic, intolerant \\
\hline Financing & Owner-managers & $\begin{array}{l}\text { Widely distributed } \\
\text { absentee share owners. }\end{array}$ \\
\hline Entrepreneurial reward & Profit stream & $\begin{array}{l}\text { Salary, fees, bonuses, } \\
\text { options (capital gains) }\end{array}$ \\
\hline Expectations & $\begin{array}{l}\text { Realistic expectations } \\
\text { based on modest self- } \\
\text { improvement }\end{array}$ & $\begin{array}{l}\text { Exaggerated expectations } \\
\text { ased on high future income }\end{array}$ \\
\hline Share speculation & Based on fundamentals & Based on sentiment \\
\hline Political culture & $\begin{array}{l}\text { Plurality of views and } \\
\text { effective debate }\end{array}$ & $\begin{array}{l}\text { Dominant view and weak } \\
\text { demoralised opposition }\end{array}$ \\
\hline Lifestyle & $\begin{array}{l}\text { Identification with family, } \\
\text { community, profession. }\end{array}$ & $\begin{array}{l}\text { Aspiration to join social } \\
\text { elite }\end{array}$ \\
\hline
\end{tabular}

